Original Research Paper

\title{
Carbon Dioxide Utilization for an Enhanced Biohydrogen Production of a Biomass Hydrolysate
}

\author{
${ }^{1,2}$ Alma Negre Abug and ${ }^{2}$ Young Sook Oh \\ ${ }^{I}$ Department of Environmental Science and Technology, \\ Mindanao University of Science and Technology, Cagayan de Oro City 9000, Philippines \\ ${ }^{2}$ Department of Environmental Engineering and Biotechnology, \\ Myongji University, San 38-2 Namdong, Yongin, Gyeonggido 449-728, Republic of Korea
}

Article history

Received: 15-05-2016

Revised: 29-07-2016

Accepted: 04-08-2016

Corresponding Author:

Alma Negre Abug

Department of Environmental

Science and Technology,

Mindanao University of Science

and Technology, Cagayan de

Oro City 9000, Philippines

Tell: +639159157681

Email: almaabug@must.edu.ph

\begin{abstract}
Bio-hydrogen $\left(\mathrm{H}_{2}\right)$ production in a thermophilic anaerobic bioreactor with carbon dioxide $\left(\mathrm{CO}_{2}\right)$ utilization at the headspace was investigated at different ratio of Biomass substrate to Microorganism (B/M). A $3 \mathrm{~mL}$ volume of $80 \% \mathrm{NaOH}(\mathrm{m} / \mathrm{v})$ solution was continuously hung at the headspace of the bioreactors to capture carbon dioxide. The utilization of $\mathrm{CO}_{2}$ at its headspace, proved to enhance bio $\mathrm{H}_{2}$ production. The highest Cumulative Biohydrogen Yield (CHY) of $131.81 \pm 3.47 \mathrm{~mL}$ $\mathrm{H}_{2} / \mathrm{gVS}$ was measured at the ratio of 8.10 parts of biomass to 0.90 parts of Acclimatized Seed Sludge (ASS), B/M 9, while 4.17 parts of similar biomass to 0.83 parts of ASS (B/M 5) had a biohydrogen production of $90.70 \pm 16.67 \mathrm{~mL}-\mathrm{H}_{2} / \mathrm{gVS}$. The $\mathrm{B} / \mathrm{M}$ of 6.12 parts of biomass to 0.88 parts

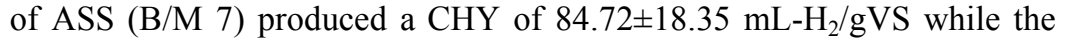
control bioreactors without $\mathrm{CO}_{2}$ utilization (without and with biomass substrate) yielded a $0.06 \pm 0.035 \mathrm{~mL}-\mathrm{H}_{2} / \mathrm{gVS}$ and a $3.27 \pm 0.78 \mathrm{~mL}_{-} \mathrm{H}_{2} / \mathrm{gVS}$ respectively. The mechanism of the biofermentation in this anaerobic reaction produced two possible resulting reaction; the acetogenesis of $\mathrm{CO}_{2}$ with $\mathrm{H}_{2}$ and the hydrogenotrophic methanogenesis. These reactions consumes hydrogen in the process to produce methane or acids. The presence of $80 \%(\mathrm{~m} / \mathrm{v}) \mathrm{NaOH}$ solution at the headspace inside the bioreactors, utilizes the $\mathrm{CO}_{2}$ producing a hydrogen-rich region in space: The highest average $\mathrm{H}_{2}$ yield of $51.83 \mathrm{~mL}-\mathrm{H}_{2}$ after $49.1 \mathrm{~h}$ with B/M 9 without methane was due to carbon dioxide utilization in the bioreactors. A univariate ANOVA and Pair-wise Tukey HSD statistical analysis revealed that the $\mathrm{CHY}$ of $\mathrm{B} / \mathrm{M} 9$ was significantly higher than the other $\mathrm{B} / \mathrm{Ms}$. The highest yield, $55.85 \mathrm{~mL}-\mathrm{H}_{2} / \mathrm{gVS}$ obtained with the bioreactor of B/M 9 was optimum for $\mathrm{H}_{2}$ production. The results concluded that $\mathrm{H}_{2}$ production is also enhanced by $\mathrm{CO}_{2}$ utilization at the headspace.
\end{abstract}

Keywords: Anaerobic Fermentation, Hydrogen Production, $\mathrm{CO}_{2}$ Capture, Thermophilic Condition

\section{Introduction}

Hydrogen $\left(\mathrm{H}_{2}\right)$ is a promising alternative to fossil fuels due to its clean and high energy yield $(122 \mathrm{~kJ} / \mathrm{g})$ and produces only water on combustion, It is environmentally friendly and is extensively used in a wide range of energy and industrial applications (Mizuno et al., 2000; Rifkin, 2002). However, approximately $96 \%$ of the hydrogen consumed comes from steam reforming of fossil fuels, such as natural gas, fuel oil and coal (Elam et al., 2003; Ewan and Allen, 2005). Since the physicochemical $\mathrm{H}_{2}$ production processes are energy-intensive and hazardous to the environment, there have been urgent needs for biological $\mathrm{H}_{2}$ production from renewable materials. Though thermo-chemical methods of producing $\mathrm{H}_{2}$ are an easier approach, biological methods are safer and economically viable (Kim et al., 2008).

Hydrogen production from biomass wastes offers a dual benefit for controlling environmental pollution 
while producing an alternative energy source. Hydrogen can be biologically produced through biophotolysis, light fermentation and dark fermentation (Nandi and Sengupta, 1998; Nath and Das, 2004). Despite the relatively lower yields of $\mathrm{H}_{2}$, dark fermentation is generally considered as the most promising method due to its higher $\mathrm{H}_{2}$ production rate in the absence of any light source as well as the variety of carbon sources as substrates. Moreover, heterotrophic fermentative microorganisms exhibit relatively high growth rates and did not show any $\mathrm{O}_{2}$-limitation problem (Hallenbeck and Benemann, 2002; Bai et al., 2004). Most of the studies on $\mathrm{H}_{2}$ production are carbohydrate-based (Bai et al., 2004; Ding et al., 2008; Lin and Lay, 2004; Roychaudhury et al., 1988; Zhang et al., 2003) since these materials can be improved by inhibition of the activity of $\mathrm{H}_{2}$-quenching pathways or by reduction of $\mathrm{H}_{2}$ and $\mathrm{CO}_{2}$ partial pressure (Nath and Das, 2004; Ewan and Allen, 2005; Kim et al., 2008; Nandi and Sengupta, 1998; Hallenbeck and Benemann, 2002; Bai et al., 2004; Ding et al., 2008; Lin and Lay, 2004; Roychaudhury et al., 1988; Zhang et al., 2003; Das and Veziroglu, 2001; Lamed et al., 1988; Oh et al., 2003; Park et al., 2005; Kim et al., 2004).

Cooked rice as a biomass waste is normally found in rice-eating countries. Its use as a substrate for $\mathrm{H}_{2}$ production has been the subject of interest for years because of its carbohydrate-rich content. On the other hand, previous studies on the condition of the inoculums have also been found to affect the amount of $\mathrm{H}_{2}$ production. Heat treatments of the inoculums were found to produce greater $\mathrm{H}_{2}$ yields $(57-72 \%)$ than with nonheat-treated inoculums (Oh et al., 2003). Similarly, the amount of $\mathrm{H}_{2}$ production from the thermophilic acidogenic culture condition was found to be higher than the mesophilic culture at all tested $\mathrm{pH}$ because of its methane-free environment and negligible propionate production (Zhang et al., 2003; Kim et al., 2004). Another condition to maximize $\mathrm{H}_{2}$ production and reduce its losses via acetogenesis is to use a chemical scavenger to reduce the carbon dioxide $\left(\mathrm{CO}_{2}\right)$ concentrations in the headspace of the bioreactors (Park et al., 2005; Stolaroff et al., 2008).

During fermentative $\mathrm{H}_{2}$ production by mixed cultures, $\mathrm{H}_{2}$ loss occurs through interspecies transfer (primarily to methane) and therefore, must be prevented. Based on a previous investigation, on biohydrogen production by dark fermentation from organic wastes and residues (Liu, D., Ph.D. thesis, Department of Environmental Engineering, Technical University of Denmark, 2008), the use of $\mathrm{pH}$ and temperature control as well as agitation seems to be the most applicable methods to prevent methanogenesis in an industrial-scale system. The highest $\mathrm{H}_{2}$ production was found at neutral $\mathrm{pH}(\mathrm{pH}$ 7). Furthermore, previous studies have also demonstrated that bioreactors running at low HRTs presented a better performance in terms of $\mathrm{H}_{2}$ production (Zhang et al., 2003; Chen et al., 2006).

Anaerobic fermentation is one of the best biotechnologies for $\mathrm{H}_{2}$ production and various fermentation conditions had been optimized. One of the approaches is the sequestration of $\mathrm{CO}_{2}$ at the headspace of the bioreactor to reduce $\mathrm{H}_{2}$ losses via acetogenesis by using $\mathrm{KOH}$ (Park et al., 2005). The $\mathrm{CO}_{2}$ capture at the headspace resulted to $\mathrm{H}_{2}$ production of $43 \%$, from 1.4 to $2.0 \mathrm{~mol}$ of $\mathrm{H}_{2} / \mathrm{mol}$ of glucose (Park et al., 2005). Another fermentation condition to maximize $\mathrm{H}_{2}$ production is to control the Food to Microorganism (F/M) ratio. The $\mathrm{F} / \mathrm{M}$ ratios between 7 and 10 were found to be appropriate for $\mathrm{H}_{2}$ production via thermophilic fermentation. Previously, the highest yield of $39 \mathrm{~mL}-\mathrm{H}_{2} / \mathrm{g}$ VS was reported at F/M ratio of 6 (Pan et al., 2008).

Thus in this study, the extent of efficiency of $\mathrm{CO}_{2}$ capturing method using $80 \%(\mathrm{w} / \mathrm{v}) \mathrm{NaOH}$ solution was investigated. The optimum $\mathrm{B} / \mathrm{M}$ ratio was also determined for an enhanced $\mathrm{H}_{2}$ production via anaerobic fermentation in thermophilic reaction using cooked rice as substrate. The combined effect of carbon dioxide capture and the optimum $\mathrm{B} / \mathrm{M}$ ratio was investigated since there were no studies if these two fermentation conditions can significantly affect the $\mathrm{H}_{2}$ production in an anaerobic fermentation condition.

\section{Materials and Methods}

\section{Preparation of Sludge}

Mesophilic seed sludge for the experiment was collected from Yongin Waste Water Treatment Plant, Gyeonggido, South Korea. Preliminary 9-day analyses of the Yongin Sewage Sludge (YSS) exposed to thermophilic conditions was done to determine its optimum production capacity. One liter of the collected sludge was placed in 2-L flask-bioreactors and was acclimatized for at least 2 days in a thermophilic condition at $50 \pm 1^{\circ} \mathrm{C}$.

After 2 days, evolved gas in the bioreactors was analyzed using Gas Chromatography (GC) to determine the activity of the sludge. Other parameters like $\mathrm{pH}$, Total Solid (TS), Volatile Solid (VS), protein, carbohydrate and lipid concentration were determined according to the Standard Methods for the Examination of Water and Wastewater Treatment (Eaton et al., 1995). Protein concentration was measured through Bio-Rad Assay for BSA using a Shimadzu UV-Visible Spectrophotometer UV-160 1PC at $595 \mathrm{~nm}$. The carbohydrate concentration was determined in terms of glucose $\left(\mathrm{CH}_{2} \mathrm{O}\right)$ units at $490 \mathrm{~nm}$ (Eaton et al., 1995). Results were analyzed against a standard calibration curve for protein and carbohydrate concentrations. 


\section{Substrate Preparation}

Rice as the substrate was cooked with water in a 1 : $1(\mathrm{v} / \mathrm{v})$ ratio using a rice cooker and was finely grounded using a Hanil Cooking Mixer, HMF-347(E) model. The parameters TS, VS, protein concentration, $\mathrm{CH}_{2} \mathrm{O}$ concentration and lipid concentration were determined when the grounded rice were mixed with the inoculums before and after anaerobic fermentation. The amount of substrates for the different $\mathrm{B} / \mathrm{Ms}$, was based on the theoretical ratio of 4.17 parts of cooked rice to 0.83 parts of Acclimatized Seed Sludge (ASS) for B/M of 5, 6.12 parts of cooked rice to 0.88 parts of ASS for $\mathrm{B} / \mathrm{M}$ of 7 and 8.1 parts of cooked rice to 0.9 parts of ASS for $\mathrm{B} / \mathrm{M}$ of 9 .

\section{Thermophilic Anaerobic Digestion Set-Up and Operation}

A series of batch experiments in duplicate, were conducted using five one-Liter glass amber bottles (SCHOTT Duran, Germany) sealed with a rubber stopper screwed with a plastic cap with sampling gas ports. Each of the three bottles was supplied with the ASS and rice with a variable ratio of $\mathrm{B} / \mathrm{Ms}$ of 5, 7 and 9 with VS loading equivalent of $3.0 \mathrm{gVS} / \mathrm{L}$ and the other two bottles served as the control set-ups supplied with ASS but without rice as substrate. Carbon dioxide capturing was done by hanging a $20 \mathrm{~mL}$-vial with 3.0 $\mathrm{mL} 80 \%(\mathrm{w} / \mathrm{v}) \mathrm{NaOH}$ solution at the headspace of the four bioreactors attached to the rubber stopper. Anaerobic fermentation was conducted with a total working volume of $0.35 \mathrm{~L}$ for each bioreactor. Each bioreactor was purged with nitrogen $\left(\mathrm{N}_{2}\right)$ gas for $10 \mathrm{~min}$ before placing it in a shaking incubator (Vision Scientific Co., LTD KMC-84080SF model) with an agitation speed of $100 \mathrm{rpm}$ at $50 \pm 1^{\circ} \mathrm{C}$ temperature. The initial pressure and $\mathrm{pH}$ in each bioreactor were determined before placing them in the incubators.

\section{Analytical Methods}

Gas samples were taken from the headspaces of the bioreactors. The amounts of biohydrogen generated from the batch fermentation were detected using GC (HP 6890 GC Method) equipped with thermal conductivity detector. Analytes were separated using packed column Cat19808 Model Number Restek with Shin Carbon ST 100/120 and $\mathrm{N}_{2}$ as the carrier gas. The temperature of the injector, oven and detector were kept at 120,150 and $180^{\circ} \mathrm{C}$ respectively with a total flow of $12 \mathrm{~mL} / \mathrm{min}$. The reference and make-up gas flow rates were set at $20 \mathrm{~mL} / \mathrm{min}$ and $7 \mathrm{~mL} / \mathrm{min}$, respectively. A biogas standard (Scott Specialty Gases, Plumsteadville) composed of $\mathrm{CH}_{4}\left(30 \%\right.$. v/v), $\mathrm{H}_{2}\left(30.1 \%\right.$. v/v) and $\mathrm{CO}_{2}$ $(39.9 \% \mathrm{v} / \mathrm{v})$ was used for calibration. The volume of the gas produced was determined using the pressure generated at the headspace as measured through a pressure transducer (WAL_BMP test system 3150. Oldenbrug) and calculated using the Ideal gas law equation corrected to standard conditions as described by Pan et al. (2008). After detection of the pressure, the biogas is released and the pressure in the headspace is again measured to serve as the initial pressure for the next sampling detection. The daily pressure detection served as the final pressure for the computation of the final volume produced using the ideal gas equation.

In all conditions for the batch experiments, the CHP was fitted to a modified Gompertz Equation (Equation 1) used as a suitable model for describing the $\mathrm{H}_{2}$ production in batches (Zhang et al., 2003; Chen et al., 2006; Pan et al., 2008; Zhang et al., 2007; Sreela-or et al., 2011):

$$
H=P \exp \left[-\exp \left\{\frac{R m e}{P}(\lambda-t)+1\right\}\right]
$$

In Equation 1, $H$ represents the cumulative volume $(\mathrm{mL})$ of $\mathrm{H}_{2}$ produced at time $t(\mathrm{~h}), P$ the $\mathrm{H}_{2}$ production potential $(\mathrm{mL}), R_{m}$ the maximum $\mathrm{H}_{2}$ production rate $(\mathrm{mL} / \mathrm{hr}), \lambda$ the lag phase time (h) and $t$ the incubation time $(h)$ (Sreela-or et al., 2011). Pearson product moment correlation coefficient $\left(r^{2}\right)$ for different trials in each sampling was used to establish reliability of the results. One-Way ANOVA for 5 independent samples and pair-wise comparisons via Tukey HSD Test were used as a statistical treatment to determine the significance of the results.

\section{Results and Discussion}

The preliminary profile for at least 9-day analyses of the sludge under thermophilic condition was used to determine the number of days required for acclimation to optimized $\mathrm{H}_{2}$ production before fermentation conditions were enhanced. Results showed that growth activity phase of the YSS starts after a day of acclimation and the optimum potential for hydrogen production is at least 2 days. These results were used as the bases for a 2-day acclimatization of the seed sludge for anaerobic batch fermentation. Such pretreatment conditions were used for anaerobic fermentation to optimized $\mathrm{H}_{2}$ production in all series of batch experimentation.

\section{Substrate Degradation}

The ASS was used for all the bioreactors at different $\mathrm{B} / \mathrm{Ms}$ with rice as the substrate. The two bioreactors that served as the control both had only ASS without the substrates but one control set-up was with $\mathrm{CO}_{2}$ capture method and the other, was without the $\mathrm{CO}_{2}$ capture method. Before and after the anaerobic fermentation, physical and chemical characteristics of the solution were examined and Table 1 shows the comparison. 
Table 1. Physical and chemical Parameters of the bioreactors under study

\begin{tabular}{lrrrrr}
\hline Parameters & $\mathrm{B} / \mathrm{M} 5$ & $\mathrm{~B} / \mathrm{M} 7$ & $\mathrm{~B} / \mathrm{M}$ & Control 1 $^{*}$ & Control 2 $^{* *}$ \\
\hline Initial pH & 7.86 & 7.73 & 7.66 & 7.81 & 7.80 \\
Final pH & 4.33 & 4.08 & 3.73 & 9.00 & 7.89 \\
VS reduction (mg/L) & 800.00 & 650.00 & 1600.00 & 1000.00 & 1150.00 \\
Carbohydrate conversion (mg/L) & 10.00 & 8.00 & 16.00 & 9.00 & 23.00 \\
Protein (mg/L) & 71.00 & 76.00 & 37.00 & 85.00 & 82.00 \\
Lipid (mg/L) & 875.00 & 1750.00 & 900.00 & 1100.00 & 750.00 \\
\hline
\end{tabular}

The values of the different parameters in Table 1 indicated an enhancement of $\mathrm{H}_{2}$ production in an anaerobic fermentation. The values in $\mathrm{mg} / \mathrm{L}$ for $\mathrm{VS}$ reduction, carbohydrate conversion, protein and lipid contents, during anaerobic fermentation provide evidence of the extent of substrate degradation for the production of $\mathrm{H}_{2}$. The final $\mathrm{pH}$ of $4.0 \pm 0.3$ (initial $\mathrm{pH}=$ $7.8 \pm 0.1$ ) at all $\mathrm{B} / \mathrm{Ms}$ validated the $\mathrm{H}_{2}$ production as pointed out by some studies on the VFA changes before and after fermentation reactions (Zhang et al., 2003; Hao et al., 2006). Fermentations at all B/Ms were remarkable as compared to the two control set-ups with final $\mathrm{pH}$ of 9.00 and 7.89 . The reduction of VS is greatest at $\mathrm{B} / \mathrm{M}$ of 9 with $1600 \mathrm{mg} \mathrm{L}^{-1}$ wherein it also had a higher carbohydrate conversion. Apparently, the hydrogen-producing bacteria in the bioreactor with $\mathrm{B} / \mathrm{M}$ 9 readily converted the soluble part of rice into hydrogen as compared to $\mathrm{B} / \mathrm{M} 7$ and $\mathrm{B} / \mathrm{M}$ 5. Nevertheless, fermentation at all $\mathrm{B} / \mathrm{Ms}$ manifested VS reduction and carbohydrate conversion for the bioreactors under study. It can be deduced from the values that the hydrogenproducing bacteria had utilized the carbohydrates for their growth and organic acid production as manifested by its protein yield and lipid-increase. Protein yield is highest at $\mathrm{B} / \mathrm{M}$ of 7 with an evidence of having the greatest lipid profile. The sludge is an organic industrial waste and may contain high amounts of lipids (Angelidaki and Ahring, 1992). Aside from the degradation of the hydrolysate, the response of a biogas process to addition of neutral lipids that is part of the inoculums may depend upon the degree of adaptation. During degradation in an anaerobic fermentation, hydrolysis of carbohydrates and other nutrients to glycerol and long fatty acids proceeds very fast and is further degraded to acetate and hydrogen. The hydrogen produced may then be further consumed if acetogenesis or hydrogenotrophic methanogenesis is not inhibited.

\section{Effects of Carbon Dioxide Capture on Hydrogen Production}

Anaerobic fermentation reactions are accompanied by $\mathrm{CO}_{2}$ and $\mathrm{HCO}_{3}^{-}$formation (Meier-Scheiders et al., 1995). $\mathrm{CO}_{2}$ is believed to be released from the cells into the solution in its dissolved form. Depending on the $\mathrm{pH}$ and partial pressure of $\mathrm{CO}_{2}$ in the fermentation, significant amounts of liquid $\mathrm{CO}_{2}$ can be in equilibrium with the gaseous $\mathrm{CO}_{2}$ or may formed into acetates. Fermentation in this study was run between $\mathrm{pH} 7.1 \pm 0.1$ and $4.0 \pm 0.3$, so significant amounts of $\mathrm{CO}_{2}$ in the gaseous phase can be released. As soon as the gaseous $\mathrm{CO}_{2}$ concentration is above the partial pressure in the headspace, desorption took place inside the vial containing the $\mathrm{NaOH}(80 \% \mathrm{w} / \mathrm{v})$ favoring $\mathrm{H}_{2}$ production along the process.

Figure 1 shows the cumulative biogas production (A) and $\mathrm{H}_{2}$ production (B) at varying $\mathrm{B} / \mathrm{Ms}$ with $\mathrm{CO}_{2}$ capture in the fermentation reactions. The bioreactor with $\mathrm{B} / \mathrm{M}$ of 9 exhibited the highest Cumulative Hydrogen Production (CHP) of $138.40 \mathrm{~mL}$ which is $41.58 \%$ of the total biogas production as compared to $95.23 \mathrm{~mL}$ $(33.81 \%)$ at $\mathrm{B} / \mathrm{M}$ of 5 and $88.95 \mathrm{~mL}(32.80 \%)$ at $\mathrm{B} / \mathrm{M}$ of 7. Since there were no $\mathrm{CH}_{4}$ and $\mathrm{CO}_{2}$ gases present in the bioreactors with $\mathrm{B} / \mathrm{M} \mathrm{5,7}$ and 9, the remaining biogas is believed to be $\mathrm{N}_{2}$ and were not detected since the carrier gas of the $\mathrm{GC}$ was $\mathrm{N}_{2}$ gas.

The highest average $\mathrm{H}_{2}$ production of $51.83 \mathrm{~mL}-\mathrm{H}_{2}$ was attained after $49.1 \mathrm{~h}$ at $\mathrm{B} / \mathrm{M}$ of $9 . \mathrm{B} / \mathrm{M} 7 \mathrm{had}$ an average of $39.97 \mathrm{~mL}^{-\mathrm{H}_{2}}$ after $86.86 \mathrm{~h}$ and $\mathrm{B} / \mathrm{M} 5 \mathrm{had}$ $32.19 \mathrm{~mL}_{-} \mathrm{H}_{2}$. From the results, it can be noted that the presence of $\mathrm{CO}_{2}$-capture system inside the bioreactors favored $\mathrm{H}_{2}$ production for all $\mathrm{B} / \mathrm{Ms}$ tested. The presence of $\mathrm{H}_{2}$ in the biogas production for all bioreactors with the $\mathrm{CO}_{2}$ capturing method pointed to the enhancing capacity of $80 \%(\mathrm{w} / \mathrm{v}) \mathrm{NaOH}$ solution inside the bioreactors especially at $\mathrm{B} / \mathrm{M}$ of 9 .

\section{Comparison of Hydrogen Yield with other Biogas}

Comparison of the other biogas yield during fermentation reaction at different $\mathrm{B} / \mathrm{Ms}$ and the two control set-ups is shown in Fig. 2.

In the Figure, no $\mathrm{CH}_{4}$ and $\mathrm{CO}_{2}$ gases were generated and only $\mathrm{H}_{2}$ was produced in all the varying $\mathrm{B} / \mathrm{M}$ ratios with $\mathrm{B} / \mathrm{M}$ of 9 exhibiting the highest $\mathrm{H}_{2}$ yield. On the other hand, negligible $\mathrm{H}_{2}$ was produced in both control set-ups with control 2 having slightly higher $\mathrm{CO}_{2}$ levels due to the absence of $\mathrm{CO}_{2}$ capture system. The absence of $\mathrm{CH}_{4}$ and $\mathrm{CO}_{2}$ as by-products of the anaerobic fermentation at all $\mathrm{B} / \mathrm{Ms}$ can be due to a number of reasons. First, the acclimatization of YSS at $50^{\circ} \mathrm{C}$ removed the non-spore-forming methanogens from the inoculums (Zhang et al., 2003; Kim et al., 2004) though some results in another study showed that heat-pretreatment inoculums did not enhance hydrogen yield (Luo et al., 2010). Second, the thermophilic condition during the entire fermentation reaction 
prevented the microbial formation of the interspecies hydrogen to methanogens, thus recovering the $\mathrm{H}_{2}$ gas in the process (Zhang et al., 2003). An increase of $69.6 \mathrm{mLH}_{2} / \mathrm{gVS}$ under thermophilic conditions was observed in some studies (Luo et al., 2010) and there was a yield of $56.6 \mathrm{mLH}_{2} / \mathrm{gVS}$ and $249 \mathrm{mLCH}_{4} / \mathrm{gVS}$ under high organic loading rate $(>10 \mathrm{gVS} /(\mathrm{L} . \mathrm{d})$ from a two-phase thermophilic CSTR for hydrogen and methane production. The temperature proved to be more important and hydrogen production can be maintained at a more stable condition of $55^{\circ} \mathrm{C}$ without significant hydrogen consumption (Lin et al., 2012). Third, the reduction of $\mathrm{pH}$ during fermentation from $\mathrm{pH} \quad 7.8 \pm 0.1$ to $\mathrm{pH} \quad 4.0 \pm 0.3$ and the constant temperature of $50 \pm 1^{\circ} \mathrm{C}$ consistently eliminated the production of measurable concentration of methane and produced greater $\mathrm{H}_{2}$ yields confirming previous studies (Oh et al., 2003; Nazlina et al., 2009). Lastly, the dominating presence of $\mathrm{H}_{2}$ in the three bioreactors (B/Ms of 5, 7 and 9) favors $\mathrm{CO}_{2}$ capture and prevented acetogenesis and hydrogenotrophic methanogenesis during the entire fermentation.

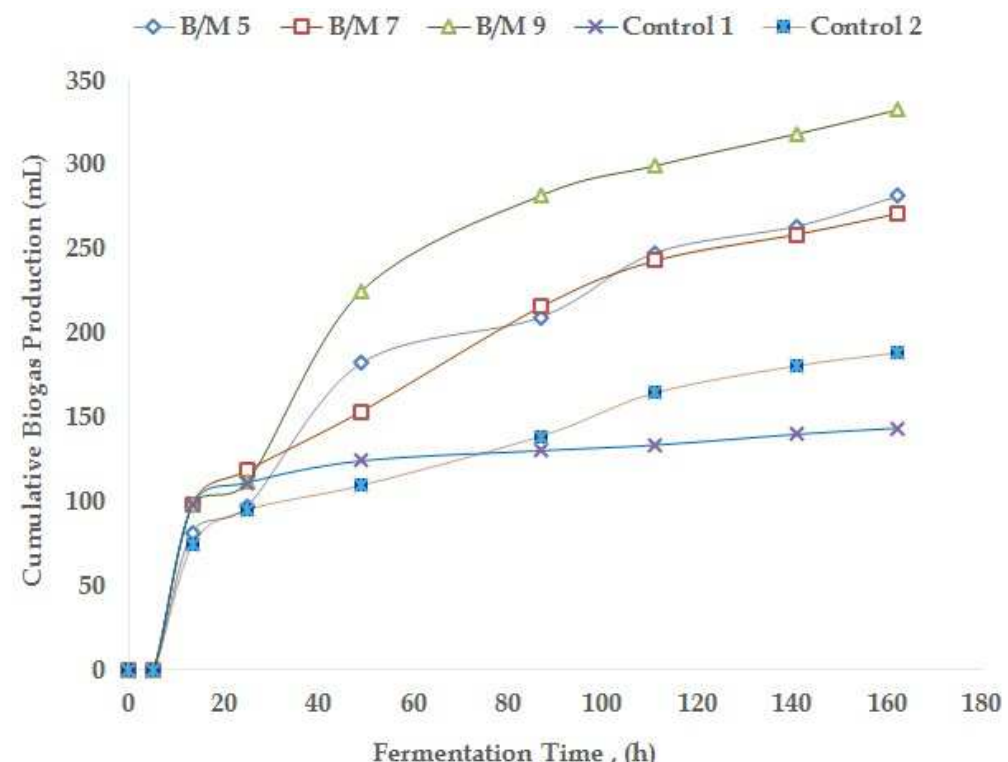

(A)

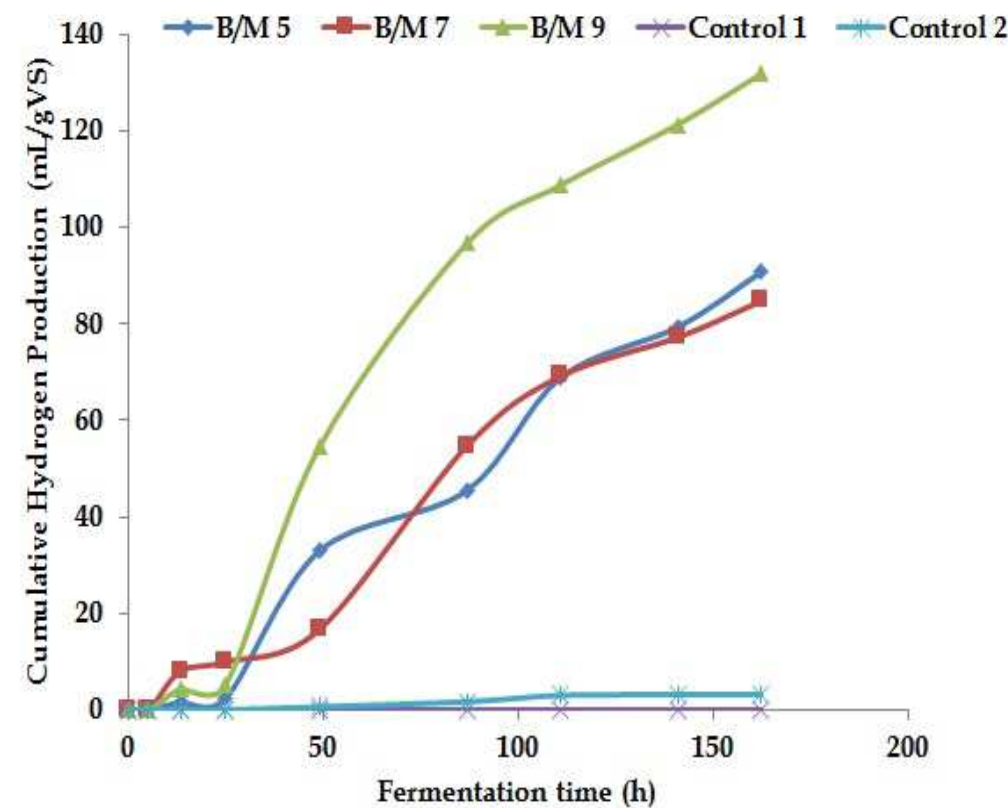

(B)

Fig. 1. Cumulative biogas production (A) and cumulative hydrogen $\left(\mathrm{H}_{2}\right)$ production (B) at varying mass to microorganism ratio during fermentation with carbon dioxide $\left(\mathrm{CO}_{2}\right)$ capture 


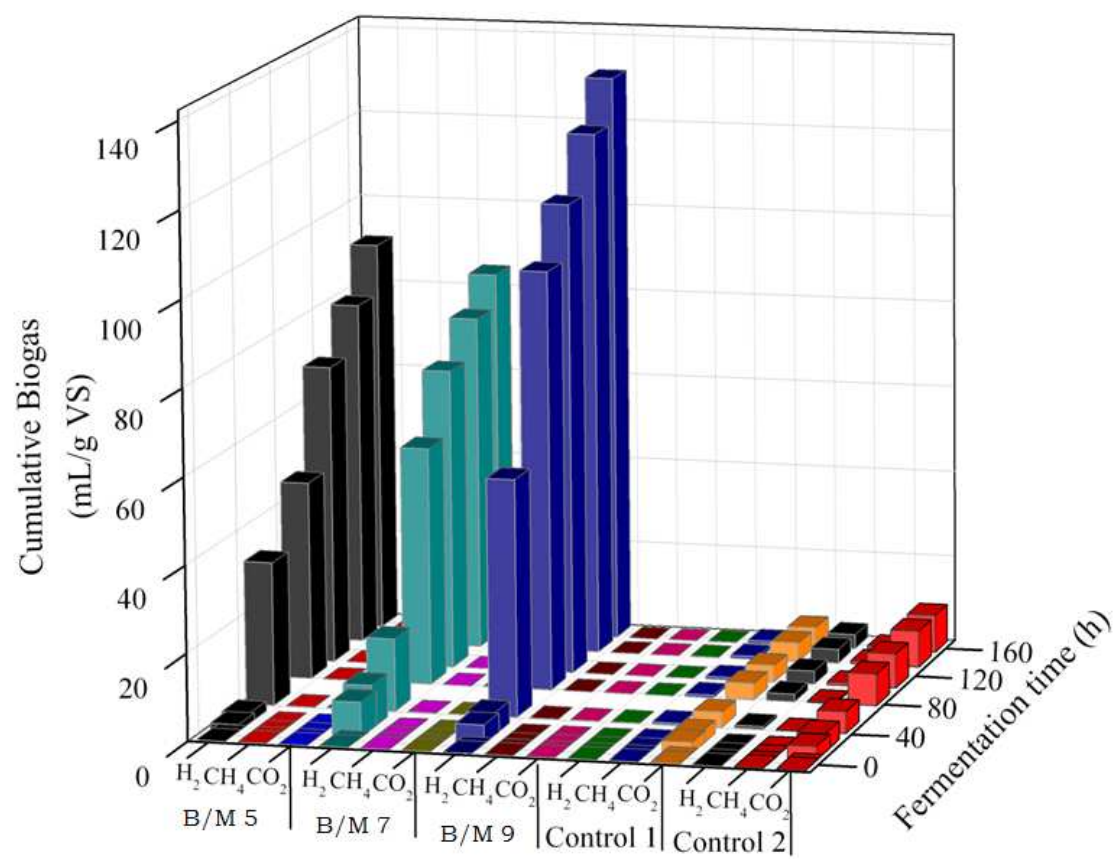

Fig. 2. Comparing biogas production; methane $\left(\mathrm{CH}_{4}\right)$ and carbon dioxide $\left(\mathrm{CO}_{2}\right)$ with hydrogen $\left(\mathrm{H}_{2}\right)$ production at varying $\mathrm{B} / \mathrm{M}$ ratio with the use of $\mathrm{CO}_{2}$ capture in an anaerobic fermentation

Table 2. Kinetic Parameters and hydrogen production yield at different $\mathrm{B} / \mathrm{M}$ ratio and time

\begin{tabular}{|c|c|c|c|c|c|c|}
\hline \multirow{2}{*}{$\begin{array}{l}\mathrm{B} / \mathrm{M} \text { ratio } \\
\mathrm{RS}: \mathrm{SS}\end{array}$} & \multirow{2}{*}{$\begin{array}{l}\text { Lag phase } \\
\lambda(\mathrm{h})\end{array}$} & \multirow{2}{*}{$\begin{array}{l}\text { Hydrogen } \\
\text { production rate, } \\
\mathrm{R}_{\mathrm{m}}(\mathrm{mL} / \mathrm{h})\end{array}$} & \multirow{2}{*}{$\begin{array}{l}\text { Hydrogen } \\
\text { potential } \\
\mathrm{P}(\mathrm{mL} / \mathrm{gVS})\end{array}$} & \multirow[b]{2}{*}{$r^{2}$} & \multicolumn{2}{|c|}{$\begin{array}{l}\text { Hydrogen production } \\
\mathrm{H}(\mathrm{mL})\end{array}$} \\
\hline & & & & & after $5 \mathrm{~h}$ & after $10 \mathrm{~h}$ \\
\hline $\mathrm{B} / \mathrm{M} 5$ & 4.21 & 1.27 & 90.70 & 0.92 & 6.49 & 10.25 \\
\hline B/M 7 & 4.79 & 1.02 & 84.72 & 0.97 & 5.7 & 8.55 \\
\hline $\mathrm{B} / \mathrm{M} 9$ & 5.46 & 4.27 & 131.81 & 1.00 & 7.77 & 21.29 \\
\hline Control $1^{*}$ & 49.9 & $4.61 \times 10^{-5}$ & 0.06 & 0.83 & $4.45 \times 10^{-5}$ & $9.28 \times 10^{-5}$ \\
\hline Control $2^{* *}$ & 4.52 & $2.68 \times 10^{-2}$ & 3.27 & 0.91 & 3 & 4 \\
\hline
\end{tabular}

${ }^{*}$ with $\mathrm{CO}_{2}$ capture; ${ }^{* *}$ w/o $\mathrm{CO}_{2}$ capture

The fermentation reaction can be generalized in the following reaction:

$\mathrm{C}_{6} \mathrm{H}_{12} \mathrm{O}_{6}+4 \mathrm{H}_{2} \mathrm{O} \rightarrow 4 \mathrm{H}_{2}+2 \mathrm{CH}_{3} \mathrm{COO}^{-}+2 \mathrm{HCO}_{3}^{-}+4 \mathrm{H}^{+}$

At such mechanism of the fermentation reaction, two possible chemical reactions may take place; one is acetogenesis from $\mathrm{CO}_{2}$ and $\mathrm{H}_{2}$ :

$$
4 \mathrm{H}_{2}+2 \mathrm{HCO}_{3}^{-}+4 \mathrm{H}^{+} \rightarrow \mathrm{CH}_{3} \mathrm{COO}^{-}+4 \mathrm{H}_{2} \mathrm{O}
$$

Another possibility is the hydrogenotrophic Methanogenesis:

$$
4 \mathrm{H}_{2}+\mathrm{HCO}_{3}^{-}+\mathrm{H}^{+} \rightarrow \mathrm{CH}_{4}+3 \mathrm{H}_{2} \mathrm{O}
$$

Such two possible reactions consume hydrogen in the process to produce methane or acids. With the presence of the hanging vial containing $3.0 \mathrm{~mL}$ of $80 \%(\mathrm{w} / \mathrm{v})$ $\mathrm{NaOH}$ solution inside the bioreactors, the following reaction have taken place in the atmosphere as $\mathrm{CO}_{2}$ capture; thus producing a hydrogen-rich region in space:

$$
\mathrm{HCO}_{3}^{-}+2 \mathrm{Na}^{+} \rightarrow \mathrm{Na}_{2} \mathrm{CO}_{3}+\mathrm{H}^{+}
$$

In this study, the highest average $\mathrm{H}_{2}$ yield of 51.83 $\mathrm{mL}-\mathrm{H}_{2}$ after $49.1 \mathrm{~h}$ at $\mathrm{B} / \mathrm{M}$ of 9 with an initial 3.0 $\mathrm{gVS} / \mathrm{L}$ and without methane production can be attributed to the presence of carbon dioxide capture in the bioreactors.

\section{Kinetic Analysis}

In terms of the kinetic parameters, comparison of the $\mathrm{H}_{2}$ production across the varying $\mathrm{B} / \mathrm{M}$ ratio using Gompertz equation is shown in Table 2. A theoretical value using Equation 1 computed at 5 and $10 \mathrm{~h}$ were 
compared based on the kinetic parameters of the different B/Ms.

The values of the lag phase for all the $3 \mathrm{~B} / \mathrm{M}$ ratio were not significantly different except the control 1 setup but the values of the production rate provided a significant difference in terms of the hydrogen potential and the hydrogen production. In all the bioreactors, $\mathrm{B} / \mathrm{M}$ of 9 has the highest production rate of $4.27 \mathrm{~mL} \mathrm{~h}^{-1}$, thus producing the highest hydrogen production as compared to the other $\mathrm{B} / \mathrm{M}$ ratio of the substrate to ASS. The longer lag phase time for control 1 set-up can be due to the absence of substrate and the presence of carbon dioxide capture. The hydrogen producing bacteria of the inoculums must have starved to death and had longer time for their adaptation to the environment to produced negligible volume of hydrogen and carbon dioxide as compared to control 2 set-ups (without $\mathrm{CO}_{2}$ capture) producing slightly higher volume of $\mathrm{H}_{2}$ and greater volume of $\mathrm{CO}_{2}$. The Pearson product moment correlation, $\mathrm{r}^{2}$, for the duplicates in all samples for each food to microorganism ratio with the two control set-ups provided a valid correlation for B/M 9 and the other two B/Ms.

\section{Statistical Analysis}

To determine the significance of the results, one-way ANOVA for 5 independent samples were used to treat the values of CHP across the $3 \mathrm{~B} / \mathrm{Ms}$ and the two control set-ups. Table 3 shows the summary of the One-way ANOVA of the five bioreactors.

The F-value of 4.79 at $\mathrm{P} \alpha 0.003$ points a significant difference among the values across the different $\mathrm{B} / \mathrm{M}$ ratio as compared to the two control set-ups. Since there were 5 independent groups compared, further analysis using Pair-wise Comparisons via Tukey HSD test was done to further identify which $\mathrm{B} / \mathrm{M}$ ratio is significantly different from the other $\mathrm{B} / \mathrm{M}$ ratios and the two control set-ups. Table 4 further pointed out the significance of the result.
The CHP values of the bioreactor with $\mathrm{B} / \mathrm{M} 5$ showed no significant result as compared to $\mathrm{B} / \mathrm{M}$ of 7 and 9 and the two control set-ups during anaerobic fermentation reaction. Results also showed that $\mathrm{B} / \mathrm{M}$ of 7 did not significantly differ from $\mathrm{B} / \mathrm{M}$ of 9 and the two control setups. Although B/M of 9 did not significantly differ from $\mathrm{B} / \mathrm{M}$ of 5 and 7 but it is significantly different as compared to the two control set-ups. The result showed that there was a significant difference in the CHP of the bioreactors at $\mathrm{B} / \mathrm{M}$ of 9 with the use of $\mathrm{CO}_{2}$ capture as compared to the two control set-ups of not having the $\mathrm{CO}_{2}$ capture.

\section{Findings}

The $\mathrm{CO}_{2}$ capture method using the $80 \%$ (w/v) $\mathrm{NaOH}$ solution enhanced $\mathrm{H}_{2}$ production for all bioreactors especially at $\mathrm{B} / \mathrm{M}$ of 9 with the highest hydrogen yield of $55.85 \mathrm{~mL} \mathrm{H}_{2} / \mathrm{gVS}$. This was better than the highest yield of $39 \mathrm{~mL}-\mathrm{H}_{2} / \mathrm{g}$ VS as reported for F/M ratio of 6 (Pan et al., 2008). The result further identify that there was not much significance across the variable $B / M$ ratio as predictor for maximum $\mathrm{H}_{2}$ production. The significant difference was brought about by the $\mathrm{CO}_{2}$ capture method in the bioreactor containing $\mathrm{B} / \mathrm{M}$ ratio 9 which was not present in the two control set-ups confirming other findings that the method favors $\mathrm{H}_{2}$ production.

The results in these data confirmed the findings of previous researches (Park et al., 2005; Zhang et al., 2007; Hao et al., 2006) that $\mathrm{H}_{2}$ production can be enhanced with thermophilic condition maintained all throughout the fermentation. Moreover, the loss of hydrogen through interspecies to promote methane can be prevented by agitation, $\mathrm{pH}$ and temperature control since the batch fermentation started out with $\mathrm{pH} 7.8 \pm 0.1$ in all conditions and the shaking condition was $100 \mathrm{rpm}$, incubated at thermophilic conditions. The combination of shaking with the $\mathrm{CO}_{2}$ capture at the headspaces of the bioreactors produced a better condition for a $\mathrm{H}_{2}$ production especially at $\mathrm{B} / \mathrm{M}$ of 9 .

Table 3. Means and F-ratio from One-way ANOVA of 5 bioreactors

\begin{tabular}{lllll}
\hline Bioreactors & Mean CHP & Standard deviation & F-ratio & Probability level \\
\hline B/M 5 & 35.69 & 37.03 & 4.79 & $0.003^{*}$ \\
B/M 7 & 35.60 & 35.27 & & \\
B/M 9 & 58.06 & 56.98 & & \\
Control 1 & 0.01 & 0.02 & & \\
Control 2 & 1.33 & 1.48 & & \\
\hline
\end{tabular}

*significant at 0.01 level

Table 4. Pair-wise comparison via Tukey HSD test

\begin{tabular}{lllll}
\hline Bioreactors & B/M 7 & B/M 9 & Control 1 & Control 2 \\
\hline B/M 5 & $\mathrm{n} / \mathrm{s}^{*}$ & $\mathrm{n} / \mathrm{s}$ & $\mathrm{n} / \mathrm{s}$ & $\mathrm{n} / \mathrm{s}$ \\
B/M 7 & & $\mathrm{n} / \mathrm{s}$ & $\mathrm{n} / \mathrm{s}$ & $\mathrm{n} / \mathrm{s}$ \\
B/M 9 & & $\mathrm{p}<0.01$ & $\mathrm{p}<0.01$ \\
Control 1 & & & $\mathrm{n} / \mathrm{s}$ \\
\hline
\end{tabular}


The increase in the $\mathrm{H}_{2}$ production must result from an aspect related to the reduced $\mathrm{CO}_{2}$ concentration in the system. The most likely explanation is that a reduction in $\mathrm{CO}_{2}$ concentration reduced hydrogen losses via acetogenesis which could not be completely inhibited ${ }^{17}$ and the shaking condition of the bioreactor. The results clearly affirmed the findings of the previous researches that $\mathrm{CO}_{2}$ trapping or scavenging is an important condition for better results (Stolaroff et al., 2008; Figueroa et al., 2008; Lewis et al., 2011). Likewise the shaking conditions or stirring also enhances the production of hydrogen especially when the anaerobic conditions are thermophilic. Furthermore, the $\mathrm{B} / \mathrm{M}$ ratio of 9 with continuous $\mathrm{CO}_{2}$ capture method using $80 \%$ (w/v) $\mathrm{NaOH}$ solution provided an enriched $\mathrm{H}_{2}$ region in the atmosphere, which enhanced its generation.

\section{Conclusion}

The result of this investigation concluded that capturing $\mathrm{CO}_{2}$, with $80 \%(\mathrm{w} / \mathrm{v}) \mathrm{NaOH}$ solution in the atmosphere of bioreactors in an anaerobic fermentation favors an enhanced production of $\mathrm{H}_{2}$ and providing a mechanism for $\mathrm{H}_{2}$-rich atmosphere thus preventing further hydrogenotrophic methanogenesis and acetogenesis in the reaction especially for Biomass to Microorganism (B/M) ratio of 9 .

The anaerobic fermentation in batches with the carbon dioxide $\left(\mathrm{CO}_{2}\right)$ scheme capture proved to be an effective means of redirecting the methanogenesis pathway to the production of more volume of hydrogen in the process. This condition of capturing carbon dioxide should be considered when doing anaerobic fermentation for an enhanced hydrogen $\left(\mathrm{H}_{2}\right)$ production. The present study proved that utilizing sodium hydroxide as a compatible reagent for carbon dioxide capture for an enhanced hydrogen production and redirecting the pathway of mechanism to control the production of methane, provide better hydrogen yield. Similar studies using reagents with similar reactivity for better hydrogen yield may be investigated in the near future with considerations on the concentrations of the substance used for carbon dioxide capture.

\section{Acknowledgement}

This research was supported by Basic Science Research Program through the National Research Foundation of Korea (NRF) funded by the Ministry of Education, Science and Technology (2010-0009660).

\section{Author's Contributions}

Alma Negre Abug: Conceived the design and performed the batch experiments and conducted statistical analyses and wrote the manuscript.
Young Sook Oh: Contributed to the conceptual development, design and review the manuscript for significant intellectual content.

\section{Ethics}

The study was conducted without the involvement of human and animal subjects and there is no conflict of interest whatsoever between the authors.

\section{References}

Angelidaki, I. and B.K. Ahring, 1992. Effects of free long-chain fatty acids on thermophilic anaerobic digestion. Applied Microbiol. Biotechnol., 37: 808-812. DOI: $10.1007 / \mathrm{BF} 00174850$

Bai, M.D., S.S. Cheng and Y.C. Chao, 2004. Effects of substrate components on hydrogen fermentation of multiple substrates. Water Sci. Technol., 50: 209-216. PMID: 15566205

Chen, W.H., S.Y. Chen, S.K. Khanal and S. Sung, 2006. Kinetic study of biological hydrogen production by anaerobic fermentation. Int. J. Hydrogen Energy, 31: 2170-2178. DOI: 10.1016/j.ijhydene.2006.02.020

Das, D. and T.N. Veziroglu, 2001. Hydrogen production by biological processes: A survey of literature. Int. J. Hydrogen Energy, 26: 13-28. DOI: 10.1016/S0360-3199(00)00058-6

Ding, H.B., S.Y. Liu, O. Stabnikova and J.Y. Wang, 2008. Effect of protein on biohydrogen production from starch of food waste. Water Sci. Technol., 57: 1031-1036. DOI: 10.2166/wst.2008.080

Eaton, A.D., L.S. Clesceri, E.W. Rice and A.E. Greenberg, 1995. Standard Methods for the Examination of Water and Wastewater. 1st Edn., American Public Health Association.

Elam, C.C., C.E. GregoirePadro, G. Sandrock, A. Luzzi and P. Lindbald et al., 2003. Realizing the hydrogen future: The international energy agency's efforts to advance hydrogen energy technologies. Int. J. Hydrogen Energy, 28: 601-607. DOI: 10.1016/S0360-3199(02)00147-7

Ewan, B.C.R. and R.W.K. Allen, 2005. A Figure of merit assessment of the routes to hydrogen. Int. J. Hydrogen Energy, 30: 809-819.

DOI: 10.1016/j.ijhydene.2005.02.003

Figueroa, J.D., T. Fout, S. Plasynski, H. McIlvried and R.D. Srivastava, 2008. Advances in $\mathrm{CO}_{2}$ capture technology-the US department of energy's carbon sequestration program. Int. J. Greenhouse Gas Control, 2: 9-20. DOI: 10.1016/S1750-5836(07)00094-1

Hallenbeck, P.C. and J.R. Benemann, 2002. Biological hydrogen production; fundamentals and limiting processes. Int. J. Hydrogen Energy, 27: 1185-1193. DOI: 10.1016/S0360-3199(02)00131-3 
Hao, X., M. Zhou, H. Yu, Q. Shen and L. Lei, 2006. Effect of sodium ion concentration on hydrogen production from sucrose by anaerobic hydrogenproducing granular sludge. Chinese J. Chem. Eng., 14: 511-517. DOI: 10.1016/ S1004-9541(06)60106-7

Kim, J.K., L. Nhat, Y.N. Chun and S.K. Kim, 2008. Hydrogen production conditions from food waste by dark fermentation with Clostridium beijerinckii KCTC 1785. Biotechnol. Bioprocess Eng., 13: 499-504. DOI: 10.1007/s12257-008-0142-0

Kim, S.H., S.K. Han and H.S. Shin, 2004. Feasibility of biohydrogen production by anaerobic co-digestion of food waste and sewage sludge. Int. J. Hydrogen Energy, 29: 1607-1616. DOI:10.1016/j.ijhydene .2004.02.018

Lamed, R.J., J.H. Lobos and T.M. Su, 1988. Effects of Stirring and Hydrogen on Fermentation Products of Clostridium thermocellum. Applied Environ. Microbiol., 54: 1216-1221.

Lewis, T., M. Fauble, B. Winter and J.C. Hemminger, 2011. $\mathrm{CO}_{2}$ Capture in amine-based aqueous solution: Role of the gas-solution interface. Angew. Chem. Int. Edit., 50: 1-5. DOI: $10.1002 /$ anie. 201101250

Lin, C.Y. and C.H. Lay, 2004. Effects of carbonate and phosphate concentrations on hydrogen production using anaerobic sewage sludge microflora. Int. J. Hydrogen Energy, 29: 275-281.

DOI: 10.1016/j.ijhydene.2003.07.002

Lin, Y.H., H.X. Zheng and M.L. Juan, 2012. Biohydrogen production using waste activated sludge as a substrate from fructose-processing wastewater treatment. Process Safety Environ. Protect., 90: 221-230. DOI: 10.1016/j.psep.2012.02.004

Luo, G., L. Xie, Z. Zou, W. Wang and Q. Zhou et al., 2010. Anaerobic treatment of cassava stillage for hydrogen and methane production in Continuously Stirred Tank Reactor (CSTR) under high Organic Loading Rate (OLR). Int. J. Hydrogen Energy, 35: 11733-11737. DOI: 10.1016/j.ijhydene.2010.08.033

Meier-Scheiders, M., F. Schafer, U. Grosshans and C. Busch, 1995. Impact of carbon dioxide evolution on the calorimetric monitoring of fermentations. Thermochimica Acta, 251: 85-97.

DOI: 10.1016/0040-6031(94)02092-3

Mizuno, O., R. Dinsdale, D.L. Hawkes and T. Noike, 2000. Enhancement of hydrogen production from glucose by nitrogen gas sparging. Bioresource Technol., 73: 59-65. DOI: $10.1016 / \mathrm{S} 0960-8524(99) 00130-3$

Nandi, R. and S. Sengupta, 1998. Microbial production of hydrogen: An overview. Crit. Rev. Microbiol., 24: 61-84. DOI: 10.1080/10408419891294181
Nath, K. and D. Das, 2004. Improvement of fermentative hydrogen production: Various approaches. Applied Microbiol. Biotechnol., 65: 520-529.

DOI: $10.1007 / \mathrm{s} 00253-004-1644-0$

Nazlina, H.M.Y., A.R. Nor Aini, F. Ismail, M.Z.M. Yusof and M.A. Hassan, 2009. Effect of different temperature, initial $\mathrm{pH}$ and substrate composition on biohydrogen production from food waste in batch fermentation. Asian J. Biotechnol., 1: 42-50. DOI: $10.3923 /$ ajbkr.2009.42.50

Oh, S.E., S.V. Ginkel and B.E. Logan, 2003. The relative effectiveness of $\mathrm{pH}$ control and heat treatment for enhancing biohydrogen gas production. Environ. Sci. Technol., 37: 5186-5190. DOI: $10.1021 / \mathrm{es} 034291 \mathrm{y}$

Pan, J., R. Zhang, H.M. El-Mashad, H. Sun and Y. Ying, 2008. Effect of food to microorganism ratio on biohydrogen production from food waste via anaerobic fermentation. Int. J. Hydrogen Energy, 33: 6968-6975. DOI: 10.1016/j.ijhydene.2008.07.130

Park, W., S.H. Hyun, S.E. Oh, B.E. Logan and I.S. Kim, 2005. Removal of headspace $\mathrm{CO}_{2}$ increases biological hydrogen production. Environ. Sci. Technol., 39: 4416-4420. DOI: 10.1021/es048569d

Rifkin, J., 2002. The Hydrogen Economy: The Creation of the Worldwide Energy Web and the Redistribution of Power on Earth. 1st Edn., J.P. Tarcher/Putnam, New York, ISBN-10: 1585421936 , pp: 294.

Roychaudhury, S., D. Cox and M. Levandowsky, 1988. Production of hydrogen by microbial fermentation. Int. J. Hydrogen Energy, 13: 407-410.

DOI: $10.1016 / 0360-3199(88) 90126-7$

Sreela-or, C., T. Imai, P. Plangklang and A. Reungsang, 2011. Optimization of key factors affecting hydrogen production from food waste by anaerobic mixed cultures. Int.. J. Hydrogen Energy, 30: 1-14. DOI: 10.1016/j.ijhydene.2011.04.136

Stolaroff, J.K., D.W. Keith and G.V. Lowry, 2008. Carbon dioxide capture from atmospheric air using sodium hydroxide spray. Environ. Sci. Technol., 42: 2728-2735. DOI: 10.1021/es702607w

Zhang, M.L., Y.T. Fan, Y.Y. Xing, C.M. Pan and G.S. Zhang et al., 2007. Enhanced biohydrogen production from cornstalk wastes with acidification pretreatment by mixed anaerobic cultures. Biomass Bioenergy, 31: 250-254.

DOI: 10.1016/j.biombioe.2006.08.004

Zhang, T., H. Liu and H.H.P. Fang, 2003. Biohydrogen production from starch in wastewater under Thermophilic condition. J. Environ. Manage., 69: 149-156. DOI: 10.1016/S0301-4797(03)00141-5 